\title{
The aryl hydrocarbon receptor in liver inflammation
}

\author{
Antonella Carambia $^{1}$ (D) Fenja Amrei Schuran ${ }^{1}$
}

Received: 9 February 2021 / Accepted: 9 May 2021 / Published online: 1 June 2021

(C) The Author(s) 2021

\begin{abstract}
The aryl hydrocarbon receptor (AHR) is a ubiquitously expressed ligand-activated transcription factor with multifaceted physiological functions. In the immune system, AHR has been unequivocally identified as a key regulatory factor that can integrate environmental, dietary, or microbial signals into innate and adaptive immune responses. Correspondingly, AHR activity seems to be most important at barrier organs, such as the gut, skin, and lung. The liver is likewise prominently exposed to gut-derived dietary or microbial AHR ligands and, moreover, generates plenty of AHR ligands itself. Yet, surprisingly little is known about the role of AHR in the regulation of hepatic immune responses, which are normally biased towards tolerance, preventing harmful inflammation in response to innocuous stimuli. In this review, we summarize the current knowledge about the role of AHR in hepatic immune responses in the healthy liver as well as in inflammatory liver disease. Moreover, we discuss AHR as a potential therapeutic target in hepatic disorders, including autoimmune liver disease, liver fibrosis, and liver cancer.
\end{abstract}

Keywords Aryl hydrocarbon receptor - AHR ligands · Hepatic immune response · Hepatic tolerance · Liver inflammation · Therapy

\section{Hepatic immune responses}

In the healthy liver, immune responses normally result in tolerance rather than inflammation. This bias towards hepatic tolerance is of paramount importance since the liver is steadily exposed to harmless but potentially immunogenic compounds, such as nutritional or microbial antigens reaching the liver via the portal blood $[1,2]$. To maintain immune homeostasis, liver non-parenchymal cells (NPCs), including dendritic cells (DCs), Kupffer cells (KCs), or liver sinusoidal endothelial cells (LSECs), function as tolerogenic scavenger and antigenpresenting cells (APCs) that regulate innate as well as adaptive immune responses. Indeed, liver NPCs have an important function in protecting the organism by clearing

This article is a contribution to the Special issue on: Mediators of liver inflammation and carcinogenesis - Guest Editors: Johannes Herkel \& Dirk Schmidt-Arras

Antonella Carambia

a.carambia@uke.de

1 Department of Medicine I, University Medical Center Hamburg-Eppendorf, Martinistr. 52, D-20246 Hamburg, Germany portal blood from gut-derived endotoxin which requires them to tolerate high endotoxin doses without releasing inflammatory cytokines. Furthermore, liver APCs promote tolerogenic CD4 as well as CD8 T cell responses to presented antigens $[1,2]$. For example, LSECs can suppress inflammatory Th1 and Th17 responses [3], induce IL-10-producing CD4+ T cells [4] and FOXP3+ regulatory $\mathrm{T}$ cells [5], or tolerize $\mathrm{CD} 8+\mathrm{T}$ cells dependent on PD-L1 [6]. Likewise, KCs have been shown to suppress CD4+ T cell responses dependent on prostaglandins [7]. Yet, hepatic tolerance and suppression of inflammation may come at the cost of increased susceptibility for liver infection or cancer [1,2]. Moreover, immune homeostasis can be perturbed by various extrinsic factors, including environmental toxins, drugs, diet, infections, or alterations in the gut microbiome $[1,8,9]$, resulting in liver disease.

The development of new therapeutic interventions that either preserve hepatic immune homeostasis or boost antiinfectious or anti-tumor immunity presupposes a more detailed understanding of the regulatory mechanisms underlying hepatic immune responses. In this article, we provide an overview of the current knowledge about the role of AHR in the regulation of hepatic immune responses in the healthy and diseased liver. Moreover, we discuss the potential of AHR as a new therapeutic target in liver disease. 


\section{AHR activation and signaling}

AHR is a ligand-activated transcription factor of the evolutionarily conserved Per-Arnt-Sim (PAS) superfamily, acting as sensors of various environmental signals. In its inactive state, AHR resides in the cytoplasm as part of a protein complex (including HSP90, p23, c-SRC, and AHR interacting protein), protected from degradation and translocation into the nucleus. Ligand binding induces conformational changes of AHR leading to dissociation of the protein complex and nuclear translocation. In the nucleus, together with its binding partner AHR nuclear translocator (ARNT), AHR can induce transcription of various target genes featuring dioxinresponsive elements (DREs) as AHR-ARNT binding sites $[10,11]$. In a negative feedback loop limiting AHR activation, degradation of AHR ligands is facilitated by cytochrome P450-dependent monooxygenases CYP1A1 and CYP1A2, which are directly activated by AHR. Moreover, the AHR repressor (AHRR), a direct downstream target of AHR, also confines AHR signaling $[10,11]$. Of note, besides binding to DREs, in complex with other transcription factors, AHR can also be recruited to other target sequences. For instance, together with RELA and RELB, AHR can bind to NF- $\mathrm{kB}$ responsive elements [12]. Moreover, AHR can also influence biological processes in a non-genomic manner. Dissociation of the cytoplasmic AHR complex upon ligand binding releases several biologically active molecules such as the cSRC protein kinase, leading to phosphorylation of multiple target genes [12]. Interestingly, AHR has also been identified as an adaptor protein of the ubiquitin ligase complex, determining substrate specificity for proteasomal degradation of steroid receptors, such as the estrogen receptor $[12,13]$, or the Peroxisome proliferator-activated receptor $\gamma$ (PPAR $\gamma)$, a central regulator of adipogenesis [14]. Figure 1 provides a schematic overview of the AHR signaling pathway.

\section{AHR ligands}

Originally, AHR had been recognized as receptor for dioxin and other pollutants and xenobiotics [11, 15]. Yet, during the last decade, a huge and still growing number of additional non-toxic nutrient-derived and endogenously generated AHR ligands have been identified. Importantly, recent studies have linked the bioavailability of particular AHR ligands, including indole derivatives of tryptophan, to the gut microbiota composition [11, 15]. Moreover, it has become evident that AHR ligands play a major role in regulation of innate as well as adaptive immune responses. Therefore, as a sensor of environmental cues, AHR can integrate signals from toxins, dietary metabolites, or microbial compounds into the immune response $[11,12,15-17]$. Yet, the actual outcome of AHR activation is determined by the respective AHR ligands that not only differ in origin, but also AHR affinity and half-life. Furthermore, the regulation of immunologically relevant genes by AHR critically depends on the contextual signals in the target cell, as AHR can form cell typedependent transcriptional complexes with various other molecules [12]. A thorough overview of known AHR ligands and their respective impact on the immune system is depicted in references 10-12. Herein, we focus specifically on AHR ligands described in the context of hepatic immune responses (Table 1).

\section{AHR immune function}

As there are several recent reviews excellently summarizing the role of AHR as a key regulatory molecule in the immune system [10-12, 16-18], the impact of AHR on immune cells is only briefly discussed here.

AHR activity has been shown to impact on a variety of innate and adaptive immune cells, including innate lymphoid cells (ILCs), T cells, B cells, DCs, and macrophages. Notably, depending on the particular cell type and contextual signals, AHR may have both pro-inflammatory and tolerogenic functions. Regarding ILCs, AHR is particularly important for the differentiation and maintenance of ILC3s, the innate counterpart of Th17/Th22 cells. Indeed, $A h r$ knockout mice have very few IL-22 producing ILC3s, resulting in increased susceptibility to bacterial infection and colitis. Thus, by fostering IL22 production, AHR is an important regulator of immune homeostasis in the gut $[19,20]$. Likewise, AHR critically influences NK cell function; upon ligand-dependent activation, AHR promotes anti-tumor cytotoxicity as well as INF $\gamma$ production [21]. Moreover, tissue residency of hepatic NK cells has been linked to AHR signaling [22].

In $T$ cells, AHR can have pro- or anti-inflammatory functions. While promoting the differentiation of inflammatory IL22-producing Th17 cells, AHR is also critically involved in the induction of regulatory $\mathrm{T}$ cell populations such as CD4+ CD25+Foxp3+ Treg or Tr1 cells [12]. In APCs, AHR has been associated with tolerance-promoting activities; indeed, in DCs, AHR can induce down-regulation of MHC II and co-stimulatory molecules and suppression of Th1- and Th17-polarizing cytokines [12]. Moreover, in DCs, AHR can induce the expression of indolamine-2,3-dioxygenase (IDO) and secretion of retinoic acid (RA), important mediators of Treg differentiation [12]. For macrophages, it has been shown that together with the transcription factor c-Maf, AHR promotes the expression of the anti-inflammatory cytokine IL10 [12]. Likewise, as a key mediator of endotoxin tolerance [23], AHR constrains the inflammatory IL-6 and TNF response to LPS in macrophages [24]. 


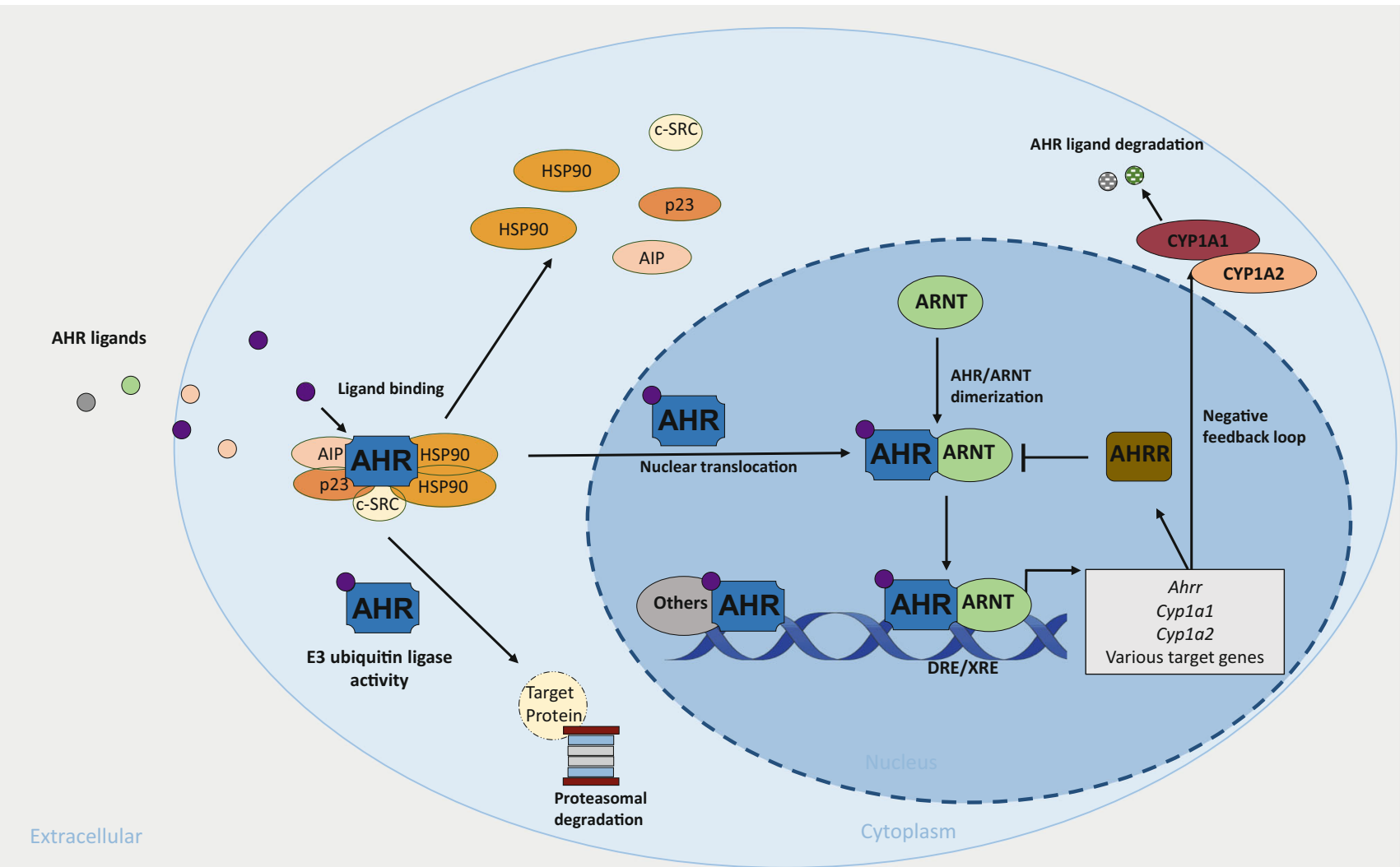

Fig. 1 AHR signaling pathway. The inactive AHR is complexed with the chaperon HSP90, co-chaperon p23, AIP, and c-SRC in the cytoplasm. Ligand binding results in conformational changes of AHR, dissociation of the protein complex, and AHR translocation into the nucleus. In the nucleus, AHR forms a heterodimer with ARNT. AHR/ARNT binds to dioxin/xenobiotic responsive elements (DRE/XRE), inducing transcription of various target genes. Additionally, in complex with other transcription factors, AHR can interact with alternative binding sites. AHR activation is limited in a negative feedback loop by the AHR repressor AHRR inhibiting AHR/ARNT dimer formation and by the AHR-induced enzymes CYP1A1 and CYP1A2 which degrade AHR ligands. Besides its transcriptional activity, AHR also functions as part of the E3 ubiquitin ligase complex driving the proteasomal degradation of target proteins, most notably of hormone receptors

\section{AHR in liver immune homeostasis}

According to its function as sensor of environmental cues, $A h r$ is highly expressed in barrier organs such as the gut, skin, and lung, as well as in the liver [17]. However, whereas AHR has been unequivocally identified as a key regulatory factor in mucosal immune regulation, the immunological relevance of AHR in the liver is only beginning to be elucidated. Nonetheless, there are several indications that AHR might regulate immune responses within the liver. Note that AHR activity is crucial for normal liver development, as reflected by decreased liver and hepatocyte size, impaired polyploidization, an immature sinusoidal architecture, the failure of neonatal ductus venosus closure, and considerable portosystemic shunting in Ahr knockout mice [25-27]. Ahr knockout mice carrying a deletion of exon 1 develop a liver pathology characterized by portal fibrosis and biliary inflammation already at the age of 3 weeks; another $A h r$ knockout strain with deletion of exon 2 seems to develop mild cholangitis and portal fibrosis only at later time-points [28-30]. The reasons for the observed phenotypical differences between $A h r$ knockout strains are not clear but might rely on several variables, including the respective gene targeting strategy that may result in altered gene products with unsuspected function or that may affect neighboring genes, as well as the type of embryonic stem cells used, or the genetic background of recipients [28]. Moreover, it has been shown that the treatment of wild-type mice with the high-affinity ligand TCDD (dioxin) leads to liver inflammation and fibrosis [31]. Regarding AHR-dependent immune regulation in the liver, it is of particular interest that tryptophan-derived tolerogenic AHR ligands, the kynurenines, are constitutively produced within the liver by the hepatocyte-specific enzyme tryptophan-2,3-dioxygenase (TDO2) [32]. Kynureninemediated AHR activation has been reported to induce immunosuppression in both T cells and APCs [12]. Likewise, in response to LPS challenge, induction of kynurenineproducing IDO1 in hepatic stellate cells (HSCs) leads to enhanced AHR signaling in thymus-derived natural Tregs, which in turn induces up-regulation of Foxp3, epigenetic stabilization, expansion, and enhanced suppressive capacity [33]. Moreover, an interesting function in the 
Table 1 Selected AHR ligands and their roles in liver disease

\begin{tabular}{|c|c|c|c|}
\hline AHR ligand & Origin & Ahr affinity & Impact on liver homeostasis \\
\hline $\begin{array}{l}\text { TCDD (=dioxin) } \\
(2,3,7,8 \text {-tetrachlorodibenzo- } p \text {-dioxin) }\end{array}$ & $\begin{array}{l}\text { Exogenous } \\
\text { Environmental } \\
\quad \text { pollutant }\end{array}$ & $\begin{array}{l}\text { High } \\
\text { No bio-degradation }\end{array}$ & $\begin{array}{l}\text { Dampens ConA-induced hepatitis via } \\
\text { myeloid-derived suppressor cells [38] } \\
\text { TCDD-exposed DCs from PBC patients promote } \\
\text { inflammatory Th1 and Th17 differentiation [44] } \\
\text { Interferes with host resistance to T. cruzi infection } \\
\text { due to impaired effector T cell subsets [46] } \\
\text { Repression of cytokine-induced acute phase genes } \\
\text { in primary hepatocytes [47] } \\
\text { Induces liver fibrosis, hepatotoxicity, and } \\
\text { inflammation [31] } \\
\text { Increases necroinflammation and hepatic stellate } \\
\text { cell activation but not hepatic fibrosis[56] }\end{array}$ \\
\hline $\begin{array}{l}\text { ITE } \\
\text { 2-(1'H-indole-3'-carbonyl)-thiazole-4-carboxylic } \\
\quad \text { acid methyl ester }\end{array}$ & $\begin{array}{l}\text { Host metabolism } \\
\text { Tryptophan derivative }\end{array}$ & High & $\begin{array}{l}\text { ITE + 3-HK: Induction of Treg cells, abolishes } \\
\text { protective immunity against } T \text {. cruzi infection } \\
\text { [46] } \\
\text { Exacerbation of acetaminophen-induced liver } \\
\text { injury via Cyp1a2 induction in hepatocytes [52] } \\
\text { Inhibition of HSC activation and prevention of } \\
\text { CC14 induced liver fibrosis [54] }\end{array}$ \\
\hline $\begin{array}{l}\text { FICZ } \\
\text { (6-Formylindolo[3,2-b]carbazole) }\end{array}$ & $\begin{array}{l}\text { Host metabolism } \\
\text { UV photo-oxidation of } \\
\text { tryptophan }\end{array}$ & High & $\begin{array}{l}\text { Exacerbation of acetaminophen-induced liver } \\
\text { injury [52] } \\
\text { Inhibits IFN- } \gamma \text { production by hepatic NKT cells in } \\
\text { ConA mediated liver injury [34] } \\
\text { Reduces alcohol induced liver pathology and } \\
\text { increases anti- microbial peptide levels in the gut } \\
\text { [49] }\end{array}$ \\
\hline $\begin{array}{l}\text { Kynurenine } \\
\text { 3-HK } \\
\text { (3-hydroxy-kynurenine) }\end{array}$ & $\begin{array}{l}\text { Host metabolism } \\
\text { Tryptophan derivatives }\end{array}$ & Low & $\begin{array}{l}\text { Kynurenines produced by IDO1 in HSCs in } \\
\text { response to LPS challenge enhance suppressive } \\
\text { capacity of nTregs [33] } \\
\text { Exacerbation of CCl4-induced acute liver injury } \\
\text { upon blockade of Kynurenine-producing IDO2 } \\
\text { [57] } \\
\text { ITE + 3-HK: Induction of Treg cells, abolishes } \\
\text { protective immunity against } T \text {. cruzi infection } \\
\text { [46] }\end{array}$ \\
\hline $\begin{array}{l}\text { I3C } \\
\text { (Indole-3-carbinol) }\end{array}$ & $\begin{array}{l}\text { Dietary } \\
\text { Glucobrassicin-deri- } \\
\text { ved Ahr ligand } \\
\text { precursor }\end{array}$ & Low & Preventive in alcohol-induced liver injury [50] \\
\hline $\begin{array}{l}\text { DIM } \\
\text { (3'3-diindolylmethane) }\end{array}$ & $\begin{array}{l}\text { Dietary } \\
\text { I3C metabolite }\end{array}$ & High & $\begin{array}{l}\text { Ameliorates experimental hepatic fibrosis by } \\
\text { downregulation of miR-21 expression [55] } \\
\text { Reduction of hepatic steatosis and progression of } \\
\text { NASH by reversing Th17/Treg imbalance to } \\
\text { Treg predominance [63] }\end{array}$ \\
\hline $\begin{array}{l}\text { ß-NF } \\
\text { ( } \beta \text {-naphthoflavone) }\end{array}$ & Dietary & Moderate & $\begin{array}{l}\text { Attenuation of cytokine-mediated acute-phase } \\
\text { response in vivo [47] }\end{array}$ \\
\hline $\begin{array}{l}\text { I3A } \\
\text { (indole-3-acetate) }\end{array}$ & $\begin{array}{l}\text { Microbiome } \\
\text { Tryptophan derivative }\end{array}$ & Low & $\begin{array}{l}\text { Inhibition of inflammatory cytokine expression in } \\
\text { macrophages in response to LPS and fatty acids } \\
\text { [48] } \\
\text { Inhibition of inflammatory hepatocyte activation in } \\
\text { response to TNF-a and fatty acids [48] }\end{array}$ \\
\hline Tryptamine & $\begin{array}{l}\text { Microbiome } \\
\text { Tryptophan derivative }\end{array}$ & Low & $\begin{array}{l}\text { Inhibition of inflammatory cytokine expression in } \\
\text { macrophages in response to LPS and fatty acids } \\
\text { [48] }\end{array}$ \\
\hline
\end{tabular}

maintenance of a newly discovered population of liverresident NK cells has been ascribed to AHR. Indeed, Ahr knockout mice display reduced numbers of these CD49a+
TRAIL+CXCR6+DX5-liver-resident NK cells, most likely depending on increased susceptibility to cytokine-induced cell death [22]. 


\section{AHR in immune-mediated liver disease}

The role of AHR in acute immune-mediated liver injury has been investigated in the Concanavalin (Con)A-model in several studies, establishing a protective function of AHR in acute immune-mediated hepatitis. Indeed, in bone marrow chimera experiments in which hematopoietic cells from $A h r$ knockout mice were adoptively transferred to irradiated wild-type recipients, Abe et al. demonstrated that increased susceptibility to ConA-mediated liver injury was due to an uncontrolled IFN- $\gamma$ response from invariant NKT cells along with decreased production of tissue-protective IL-22 by ILCs [34]. The crucial role of AHR in the induction of IL-22 and protection from immune-mediated liver injury was further linked to Notch signaling. Notably, Notch induced the expression of endogenous AHR ligands and IL-22 in CD4+ T cells, which in turn fostered AHR-dependent induction of protective IL-22 [35]. Along these lines, a second study from the same group investigating the impact of IL-23 in acute liver injury confirmed a regulatory role of AHR by fine-tuning pro-inflammatory IL17 as well as protective IL-22 responses [36]. Furthermore, the repression of AHR-dependent IL-22 expression in CD4+ $\mathrm{T}$ cells by microRNA $15 \mathrm{a} / 16-1$ led to exacerbated liver inflammation following ConA challenge, confirming the key role of AHR in controlling inflammatory responses in acute liver injury induced by ConA [37]. Interestingly, in a recent study, AHR has also been implicated in induction and mobilization of highly immunosuppressive myeloid-derived suppressor cells (MDSCs) from the peritoneal cavity. Accordingly, in adoptive transfer experiments, MDSCs induced by the AHR ligand TCDD dampened ConA-induced hepatitis [38].

There is increasing evidence that impairment of AHR might also be involved in the pathogenesis of immunemediated liver diseases in humans. It is likely that the dual function of AHR in supporting either tolerogenic or inflammatory $\mathrm{T}$ cell responses, i.e., for example through induction of Treg or Th17 differentiation, might be important for hepatic immune regulation. Indeed, higher frequencies of Th17 cells and Treg impairment are implicated in the pathogenesis of autoimmune liver diseases [39, 40]. Recently, Vuerich et al. investigated the impact of AHR signaling on the surface expression of CD39 on Th17 and Treg cells in autoimmune hepatitis (AIH) [41]. In their former studies, the same group suggested that impaired expression of CD39, an ATPdegrading ectoenzyme that fosters the production of immunosuppressive adenosine, both, on Treg and Th17 cells is a major cause of autoimmune pathology in AIH [42]. Here, the authors suggest a link between defective AHR signaling and loss of CD39 expression and function in Tregs and Th17 cells from AIH patients. Indeed, upon AHR stimulation in vitro, Tregs and Th17 cells derived from AIH patients showed less CD39 expression and activity as well as decreased Treg suppressor function in comparison to Tregs and Th17 cells from healthy donors. Loss of immune homeostasis in AIH patients with impaired AHR activity was attributed to increased expression of the AHR repressor AHRR and high levels of HIF- $1 \alpha$, a competitive binding partner for ARNT, thereby inhibiting AHR signal transduction and consequently CD39 in Tregs and Th17 cells in human AIH. Furthermore, the authors observed preferential binding of AHR to the estrogen receptor ER $\alpha$ rather than to ARNT, fostering noncanonical AHR signaling instead of CD39 expression relying on signal transduction via AHR/ARNT [41]. In autoimmune cholangitis, analysis of peribiliary infiltrates in human liver tissue demonstrated the presence of CCR6+ CD4+ and AHR $+\mathrm{CD} 4+\mathrm{T}$ cells that could potentially develop into Th17 cells under the influence of biliary epithelial cell-derived IL-1 and IL-6 and the CCR6 ligand CCL20 [43]. Regarding primary biliary cholangitis (PBC), there is emerging evidence that AHR might be involved in dysregulation of $\mathrm{T}$ cell responses. Consistent with the notion that AHR-activating dioxins might be risk factors for the development of autoimmune disease [44], She et al. reported that DCs derived from PBC patients but not from healthy donors enhanced inflammatory Th1 and Th17 differentiation upon TCDD exposure [44]. In dnTGF $\beta$ RIIdeficient mice, a spontaneous model for $\mathrm{PBC}$, microarray analysis linked dysfunctional Treg showing reduced suppressive capacity and acquisition of inflammatory features to the down-regulation of AHR and other critical transcription factors in Tregs. Therefore, the authors suggest further analysis of potentially aberrant signaling pathways, including the AHR pathway in Tregs from human PBC patients [45].

Interestingly, AHR has also been implicated as immunoregulatory factor in liver infection. Indeed, Trypanosoma cruziinfected Ahrd mice, which display a mutant AHR with low ligand affinity, displayed low numbers of Tregs, an effective Th1 response, development of CD8+ T cell memory subsets, and consequently low parasite burden. Of note, the concomitant induction of systemic IL-10 constricted the anti-infectious immune response and prevented liver immunopathology [46].

Notably, also the acute phase response in the liver seems to depend on AHR. Patel et al. showed that via repression of the NF-KB pathway, AHR regulates the expression of cytokineinduced acute phase genes such as SAA1/2. Likewise, dietary supplementation with AHR ligands resulted in downregulation of the acute phase response in vivo. Therefore, the authors suggest a key role of AHR in regulation of liver inflammation that might be targeted therapeutically [47].

In conclusion, the currently available literature suggests that depending on the respective disease, the particular cell type, and the activating ligands, AHR seems to have predominantly anti-inflammatory and tissue-protective function in immune-mediated liver disease. 


\section{AHR and the gut-liver axis}

As described above, the gut microbiome is a major source of endogenous AHR ligands. Indeed, certain commensal bacteria, for example Lactobacillus reuteri, can produce tryptophan-derived AHR ligands that suppress inflammatory immune responses in the gut. Likewise, also pathogens, including Mycobacterium tuberculosis, seem to produce immunosuppressive AHR ligands as an immune escape mechanism [11]. Along the gut-liver axis, such AHR ligands produced by gut microbiota might reach the liver via the portal blood and shape immune responses locally in the liver. In light of the hypothesis that intestinal dysbiosis might be a key driver in the pathogenesis of fatty liver disease, a recent study by Krishnan et al. analyzed the metabolite profile of germ-free versus conventionally housed mice fed a low- or high-fat diet (HFD). Interestingly, they found decreased levels of the tryptophan-derived AHR ligands tryptamine and indole-3acetate (I3A) in HFD-fed mice. Mechanistically, these AHR ligands attenuated the inflammatory TNF- $\alpha$, IL- $1 \beta$, and monocyte chemoattractant protein-1 response of macrophages following stimulation with LPS and palmitate acid, mimicking two typical insults in NAFLD. Moreover, I3A restricted the expression of the AHR-regulated lipogenesis enzymes fatty acid synthase (Fasn), and the cholesterol metabolism regulator sterol regulatory element-binding protein-1c (SREBP1c) in hepatocytes. Therefore, depletion of gut-derived AHR ligands seems to be a major determinant for the progression of NAFLD [48]. Accordingly, in alcohol-induced liver injury, abundance of microbiota-derived tryptophan metabolites that signal through AHR as well as treatment with the AHR ligands FICZ [49] or I3C [50] reduced liver pathology. Conversely, Ahr knockout mice showed increased susceptibility to ethanol-induced liver damage. In patients, alcoholic liver disease was associated with low levels of intestinal microbiota-derived tryptophan metabolites, underscoring the clinical impact of the AHR pathway in alcoholic liver disease [49]. Interestingly, the alteration in gut microbiota composition has also been implicated as a risk factor for exacerbated acetaminophen-induced acute liver injury [51]. Although here, the underlying molecular mechanisms were not focus of the study, it is likely that dysbiosis was accompanied with changes in gut bacteria-derived metabolites, including AHR ligands. Accordingly, in our recent study, we demonstrated that the tryptophan derivative ITE that can be produced in the gut strongly exacerbated acetaminophen (APAP)-induced hepatotoxicity by directly activating AHR and the APAPmetabolizing enzyme CYP1A2 in hepatocytes [52]. Therefore, endogenous AHR ligands that can be produced by the intestinal microbiome might increase susceptibility to APAP hepatotoxicity. Note that presumably depending on the underlying pathogenic mechanisms, hepatic AHR activation can have both beneficial effects, as described in alcohol- induced liver injury [49,50], and detrimental effects, as shown for acetaminophen-induced acute liver injury [52].

Moreover, besides the well-described AHR ligands derived from tryptophan, microbiota-derived short chain fatty acids (SCFA) that induce IL-22 production in the gut also seem to activate AHR [53]. Although the role of SCFA in hepatic immune responses has not been elucidated yet, it is tempting to speculate that SCFA might also activate AHR in the liver and thereby influence hepatic immune homeostasis.

\section{AHR in liver fibrosis and NASH}

Already in 1995, Fernandez-Salguero et al. described hepatic fibrosis in $A h r$ knockout mice, which appeared to be rather mild and confined to the bile ducts [28]. However, the role of AHR in liver fibrosis remains controversial, as both loss and exacerbation of AHR activity seem to induce liver fibrosis [29, 54-57]. In an elegant study, using wild-type or conditional $A h r$ knockout mice that lacked $A h r$ in hepatocytes, Kupffer cells, or stellate cells, Yan et al. dissected the respective contribution of AHR activation in different liver cell types to fibrosis development in mouse models of CCl4-induced fibrosis or bile duct ligation. They found that $A h r$-deficient HSCs were more sensitive to activation, whereas treatment with AHR ligands suppressed TGF $\beta$-induced murine and human HSC activation. Most interestingly, specific disruption of $A h r$ in HSC but not other liver cells was causative for enhanced fibrogenesis. Moreover, in the CCl4 model, application of ITE could prevent fibrosis induction, suggesting AHR in HSCs as a potential target for the treatment of liver fibrosis [54]. In support of this notion, application of the AHR ligand 3'3diindolylmethane (DIM), a metabolite of I3C, was likewise protective in murine liver fibrosis. Yet, in this study, AHR signaling was not directly addressed [55]. However, in another study, an adverse effect of AHR in liver fibrosis has been observed. Herein, the authors show a shifted balance towards more IL-17+ CD4+ T cells and less FOXP3high Tregs as well as increased IL-17 and IL-22 production in advanced fibrosis. Blocking of IL-22 production by administration of an AHR antagonist inhibited fibrogenesis in mouse models of liver fibrosis. In conclusion, AHR seems to be an important mediator of type 3 inflammation in the course of liver fibrogenesis that is mainly mediated by IL-17 and IL-22 [56]. The role of AHR in CCl4-induced acute liver injury and liver fibrosis had been further addressed by Hoshi et al., showing that blockade of AHR signaling via inhibition of the kynurenine-producing enzyme IDO2 attenuated acute liver damage and also liver fibrosis upon repeated CCl4 application [57]. The observed discrepancies regarding the role of AHR in liver fibrogenesis might at least in part be explained by different experimental approaches. Indeed, Hoshi et al. focused specifically on the AHR ligand kynurenine and IDO2, while Yan et al. used 
conditional Ahr knockout mice and the high-affinity AHR ligands ITE and TCDD in their study. Taken together, the role of AHR in liver fibrogenesis seems rather complex and is only beginning to be understood.

In the last couple of years, several studies addressing AHR function in nonalcoholic steatohepatitis (NASH) and nonalcoholic fatty liver disease (NAFLD) have emerged. Making use of mice with constitutive or defective AHR signaling, Lee et al. investigated the contribution of AHR to steatosis development. Interestingly, they identified CD36 as a new AHR target and linked steatosis-promoting AHR activation to increased expression of CD36 and lipid uptake into liver cells via CD36. Therefore, the authors suggest AHR and CD36 as novel therapeutic targets in fatty liver disease [58]. Based on the putative NAFLD-promoting role of AHR, Xia et al. tested the AHR inhibitor alpha-naphthoflavone (ANF) as therapeutic regimen in HFD-fed mice. They found that ANF treatment indeed reduced the expression of $A h r$ and the downstream molecules Cypla1 and Tnf- $\alpha$, leading to reduced oxidative stress, insulin resistance, and attenuation of NAFLD [59]. Accordingly, the pro-steatotic effect of AHR via CYP1A1 activation had been further linked to estrogen metabolism, as estrogen degradation by CYP1A1 diminished the known protective effect of $17 \beta-$ estradiol (E2) on steatosis [60]. In a study using mice with constitutive expression of human $A H R$ specifically in the liver, fibroblast growth factor 21 (FGF21) could be identified as a direct AHR target and a major mediator of both hepatic steatosis and systemic insulin hypersensitivity [61]. However, protective effects of AHR in hepatic steatosis have also been suggested. As described above, gut microbiota-derived AHR ligands can attenuate inflammatory macrophage responses and lipogenesis in hepatocytes [48]. Likewise, high fat diet-fed mice with liver-specific $A h r$ knockout displayed severe steatosis and liver inflammation owed to up-regulated de novo lipogenesis. Lipotoxicity was linked to decreased hepatic expression of the newly identified AHR target gene suppressor of cytokine signal 3 (Socs3) [62]. Moreover, in order to reverse the shifted Th17/Treg balance in NASH, the AHR ligand DIM was tested in methionine-choline-deficient (MCD)-diet fed mice. Notably, DIM administration reversed the Th17/Treg imbalance to a Treg predominance, resulting in attenuation of hepatic steatosis and inflammation [63].

\section{AHR in hepatocellular carcinoma}

AHR is involved in carcinogenesis in various cancers, influencing all major stages of tumor development, i.e., initiation, progression, and metastasis formation. Whereas the exogenous AHR ligand dioxin has long been recognized as carcinogen, recent progress has been made in determining the relevance of endogenous AHR ligands that seem to significantly contribute to tumor immune escape. Of note, AHR ligands contributing to an immunosuppressive niche can be produced by the host tissue but also by the tumor itself. Indeed, tumor cells and infiltrating immune cells such as DCs and macrophages can up-regulate the kynurenine producing enzymes TDO and IDO1. In conjunction with increased AHR expression, this can result in sustained AHR activation and perpetuation of a pro-tumorigenic immunosuppressive microenvironment [64].

In diethylnitrosamine (DEN)-induced hepatocarcinogenesis, Ido knockout mice showed significantly less tumor burden than their wild-type counterparts, which overexpressed IDO and L-kynurenine in hepatocellular carcinoma (HCC) as compared to surrounding tissue. The protection of Ido knockout mice was associated with an increased expression of $\mathrm{CD} 8$, as well as cytotoxicity-related genes, including granzyme B and perforin in hepatic tumors [65]. In $\mathrm{HCC}$, Wang et al. recently deciphered an important molecular circuit in which the proto-oncogene intestine specific homeobox (ISX) induced IL-6-dependent up-regulation of TDO and IDO1. The resulting increased kynurenine/AHR signaling further promoted ISX expression. Notably, this positive feedback loop resulted in increased tumor cell proliferation, upregulation of the immune checkpoint molecule PD-L1, and an impaired $\mathrm{CD} 8+\mathrm{T}$ cell response, partly explaining tumor immune escape in HCC [66]. In line with these findings, expression of AHR, together with IDO1, kynurenine, and PDL1, correlated with poor prognosis in hepatocellular carcinoma patients [66]. Tissue microarray analysis of $153 \mathrm{HCC}$ patients confirmed a negative correlation of IDO expression and overall survival [67]. Likewise, as a promoter of HCC proliferation and tumor invasion, TDO has also been suggested as a new prognostic biomarker of HCC [68].

Whereas the role of AHR in establishing an immunosuppressive tumor niche is well recognized, it remains unclear, whether AHR activation in hepatic progenitor cells might impact on liver carcinogenesis. Indeed, there are some reports by the group of Vondráček et al., showing that AHR ligands affect several potentially tumor-promoting processes and signaling pathways in liver progenitor cells, such as $\mathrm{Wnt} / \beta$ catenin signaling [69-71]. Likewise, Moreno-Marín et al. suggested that AHR-mediated regulation of stem-like liver cell expansion and pluripotency is an important control mechanism of liver regeneration and suppression of carcinogenesis [72]. Note, however, that these studies were mainly conducted in cell culture models and that the general in vivo relevance of hepatic progenitor cells in liver injury and regeneration is still highly controversial [73].

\section{AHR as therapeutic target in liver disease}

The manifold functions of AHR in regulating inflammatory, fibrogenic, or tumorigenic processes in the liver suggest AHR 
as a promising therapeutic target in various liver diseases. Given that in several mouse models of autoimmune disease, including experimental autoimmune encephalomyelitis, diabetes, or psoriasis, endogenous non-toxic AHR ligands have already been successfully tested as potent immunosuppressive agents $[12,16,17]$, it is conceivable that such AHR ligands might also be of therapeutic value in autoimmune diseases targeting the liver. In support of this notion, AHR dysfunction has been recently linked to autoimmune hepatitis [41]. Likewise, although so far only demonstrated in mice, attenuation of the acute phase response by dietary AHR ligands [47], prevention of liver fibrosis by application of ITE [54], or of alcohol-induced liver injury by FICZ [49] further suggest
AHR ligands as new therapeutic regimens in liver disease. Vice versa, in liver infection, inhibition of AHR might boost anti-infectious immunity, as shown in Trypanosoma cruzi infection [46]. Moreover, targeting the IDO1/TDO2kynurenine-AHR pathway to restore potent anti-tumor immune responses is an important goal of cancer immunotherapy $[74,75]$, which might be highly relevant for HCC and cholangiocarcinoma therapy.

Of note, knowledge about the kinetics of AHR ligand activity is an important prerequisite for therapeutic application. On the one hand, sufficient bioavailability is important for effectiveness; on the other hand, persistence of AHR ligand binding might have adverse effects [76]. Moreover, there is

Table 2 Cell type specific regulatory effects of AHR in liver disease

\begin{tabular}{|c|c|c|c|c|c|}
\hline Cell type & AHR ligand & AHR target genes & $\begin{array}{l}\text { Disease-promoting (+) or disease-attenuating (-) AHR } \\
\text { effects }\end{array}$ & $\begin{array}{l}\text { Use of cell-spec. } \\
\text { Ahr KO }\end{array}$ & Ref. \\
\hline \multirow[t]{11}{*}{ Hepatocytes } & B-NF & NFKB & Acute phase response (-) & Yes & {$[47]$} \\
\hline & $\mathrm{I} 3 \mathrm{~A}$ & Fasn, SREBP-1c & Lipogenesis (-) & No & [48] \\
\hline & ITE, FICZ & Cyp1a2 & APAP hepatotoxicity $(+)$ & Yes & {$[52]$} \\
\hline & $\begin{array}{l}\text { FICZ [49], } \\
\text { I3C [50] }\end{array}$ & $\begin{array}{l}\text { Cyp1a1 [49], } \\
\text { Scd1 [49] }\end{array}$ & Alcohol-induced liver injury (-) & Yes & {$[49,50]$} \\
\hline & Dioxin & $\begin{array}{l}\text { Cyp1a1, Cyp1a2, } \\
\text { Cyp1b1 }\end{array}$ & Hepatotoxicity (+) & Yes & {$[27]$} \\
\hline & TCDD & Cyp1a2, CD36 & Steatosis $(+)$ & No & {$[58]$} \\
\hline & ANF & Cyp1a1, TNF- $\alpha$ & Oxidative stress $(+)$, insulin resistance $(+)$, NAFLD $(+)$ & No & {$[59]$} \\
\hline & $\mathrm{BaP}$ & Cypla1 & Estrogen degradation $(+)$, steatosis $(+)$ & No & {$[60]$} \\
\hline & TCDD & Fgf 21 & Steatosis (+), systemic insulin hypersensitivity (+) & No & {$[61]$} \\
\hline & $3 \mathrm{MC}$ & Socs 3 & $\begin{array}{l}\text { Lipogenesis (-), steatosis (-), liver inflammation (-) under } \\
\text { HFD }\end{array}$ & Yes & {$[62]$} \\
\hline & Kyn & Cypla1 & IDO2 induction, CCl4-induced acute liver injury (+) & No & {$[57]$} \\
\hline $\begin{array}{l}\text { Endothelial } \\
\text { cells }\end{array}$ & Unknown & Unknown & $\begin{array}{l}\text { Failure of ductus venosus closure, immature sinusoidal } \\
\text { architecture, portal hypertension }\end{array}$ & Yes & {$[27]$} \\
\hline \multirow[t]{2}{*}{ HSCs } & Kyn & Cyp1b1 & $\begin{array}{l}\text { Kynurenine-derived from HSC fosters Treg expansion and } \\
\text { function }\end{array}$ & No & {$[33]$} \\
\hline & ITE & $\beta$-Catenin, Smad3 & HSC activation (-), fibrogenesis (-) & Yes & {$[54]$} \\
\hline Macrophages & I3A, tryptamine & $\begin{array}{l}\text { TNF- } \alpha, \text { IL-1 } \beta \\
\text { MCP-1 }\end{array}$ & Inflammatory mediators $(+)$ & Yes & {$[48]$} \\
\hline $\begin{array}{r}\text { DCs (PBC } \\
\text { patients) }\end{array}$ & TCDD & Cyp1a1 & Induction of Th1 and Th17 response (+) & Human & {$[44]$} \\
\hline $\begin{array}{l}\text { Invariant } \\
\text { NKTs }\end{array}$ & FICZ & $\mathrm{IFN}-\gamma$ & $\begin{array}{l}\text { Tissue residency (+), IFN- } \gamma \text { production (-), ConA hepatitis } \\
(-)\end{array}$ & No & {$[34]$} \\
\hline MDSCs & TCDD, 3MC & $\begin{array}{l}\text { CXCR2, miR-150-5p } \\
\text { miR-543-3p }\end{array}$ & MDSC induction, ConA hepatitis (-) & No & {$[38]$} \\
\hline ILCs & FICZ & IL-22 & IL-22 induction, ConA hepatitis (-) & No & {$[34]$} \\
\hline $\mathrm{CD} 4+\mathrm{T}$ cells & $\begin{array}{l}\text { N2ICD [35], } \\
\quad \text { miR15a/16-1 } \\
\text { [37] }\end{array}$ & $\begin{array}{l}\text { IL-22 [35,37], } \\
\text { Cyp1a1 [35] }\end{array}$ & IL-22 induction, ConA hepatitis (-) & No & {$[35,37]$} \\
\hline \multirow[t]{3}{*}{ Tregs, Th17 } & $\begin{array}{l}\text { UCB, quercetin, } \\
\text { Kyn }\end{array}$ & $\begin{array}{l}\text { Cyp1a1, } \\
\text { CD39, } \\
\text { ER- } \alpha, \\
\text { HIF1- } \alpha\end{array}$ & $\begin{array}{l}\text { Impaired AHR and CD39 expression correlates with AIH } \\
\text { severity }\end{array}$ & Human & [41] \\
\hline & DIM & Cyp1a1, Cyp1b1 & $\begin{array}{l}\text { Treg (+), Th17 (-), inflammation (-), steatosis (-) under } \\
\text { MCD-diet }\end{array}$ & No & {$[63]$} \\
\hline & Kyn & ISX & $\begin{array}{l}\text { TDO }(+), \text { IDO1 }(+), \text { PD-L1 (+), CD8 T cell response }(-) \text {, } \\
\text { tumor cell proliferation }(+) \text { in HCC }\end{array}$ & Human & {$[66]$} \\
\hline
\end{tabular}


accumulating evidence that many AHR ligands exert their functions in an organ- or cell-specific manner [76-78] Table 2, offering the opportunity for the selection of specific AHR ligands or the design of tailor-made synthetic AHR agonists or antagonists according to the respective therapeutic indication $[77,78]$. However, a major caveat for the pharmaceutical use of such selective AHR modulators remains the limited predictability of their in vivo function, requiring extensive testing in order to prevent unwanted side effects [77, $78]$.

\section{Concluding remarks}

Although we are only beginning to understand the complex role of AHR in hepatic homeostasis and disease, it has become unequivocally clear that AHR is an important regulator of metabolic and immunological processes in the liver (Fig. 2). Whereas in immune-mediated liver disease, the current literature rather suggests an immunosuppressive function of AHR, the role of AHR in liver fibrosis or NASH remains ambiguous. Indeed, there is evidence for both beneficial and detrimental effects of AHR signaling, most likely depending on the respective experimental setup and the presence of contextual signals. Likewise, while the outcome of AHR activation in acute acetaminophen-liver injury is exacerbation of liver damage, AHR ligands seem to have beneficial effects in ethanolinduced liver injury. Therefore, in order to develop AHRbased therapeutic strategies for liver disorders, a thorough understanding of AHR function in the respective diseasedriving pathways is required. Moreover, given that AHR is widely expressed throughout the body and has pleiotropic functions, targeting strategies for specific delivery of AHR agonists or antagonists to the relevant target cells, such as

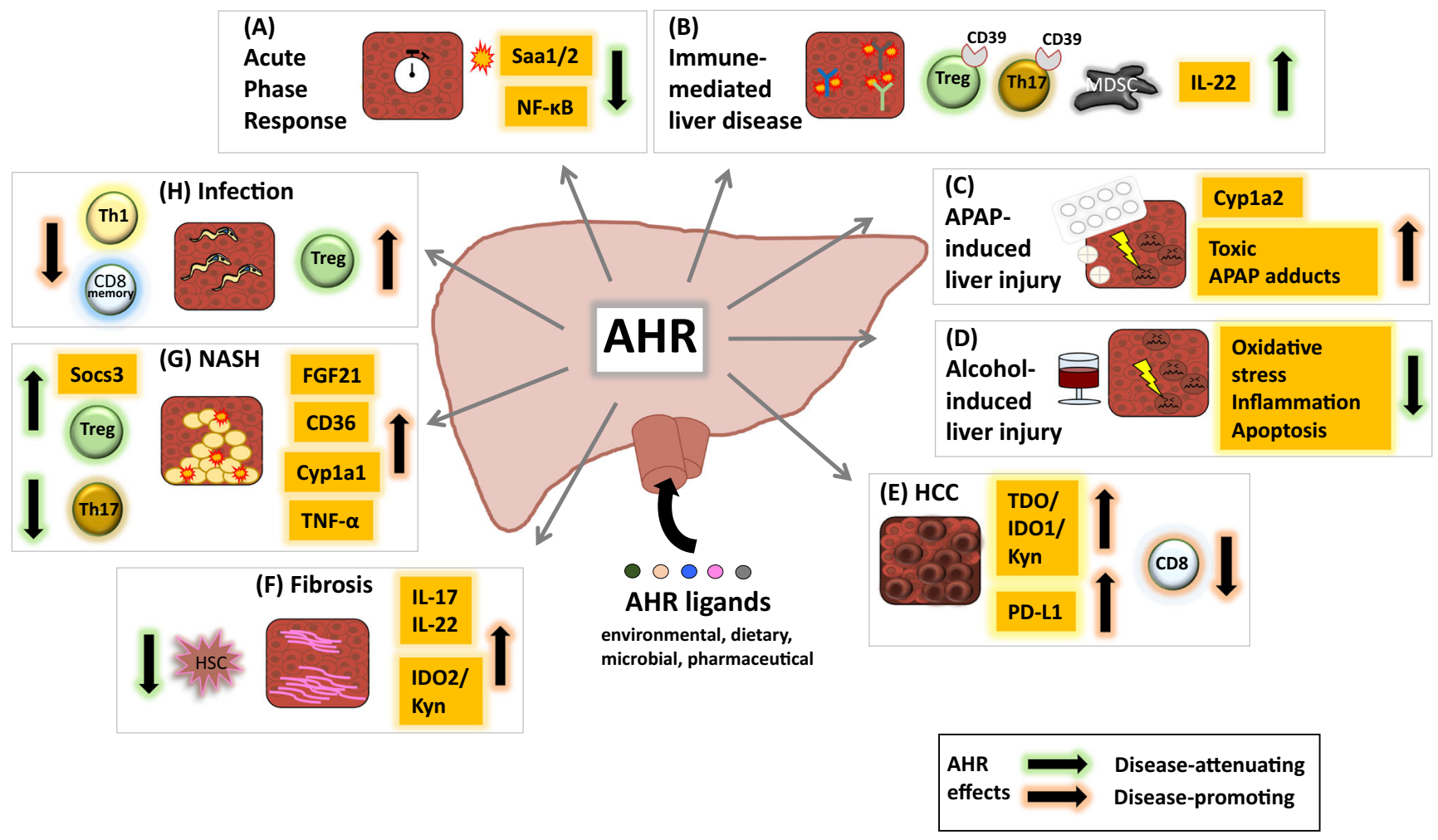

Fig. 2 Functional role of AHR in liver disease. AHR activation can promote or dampen liver disease pathogenesis, as indicated by red or green arrows, respectively. AHR activating ligands can derive from various endogenous or exogenous sources or can be produced in the liver itself (see Table 1). (A) Acute phase response: AHR activation impairs NF-KB-mediated expression of acute phase genes such as Saa1/2 [47]. (B) Immune-mediated liver disease: anti-inflammatory CD39 expression on Treg or Th17 cells is AHR dependent [41]. AHRmediated induction of suppressive MDSCs [38]. AHR controls protective IL-22 expression in ILCs and CD4+ T cells [34, 35, 37]. (C) APAPinduced liver injury: AHR activation induces the APAP-metabolizing enzyme CYP1A2, resulting in increased hepatotoxicity [52]. (D) Alcohol-induced liver injury: AHR activation reduces EtOH-induced oxidative stress, inflammation, and hepatocyte apoptosis [49, 50]. (E) HCC: increased production of the AHR ligand kynurenine via TDO and IDO1 results in upregulation of PD-L1, impaired CD8 T cell responses, and tumor progression [65-68]. (F) Fibrosis: AHRdependent IL-17 and IL-22 production as well as AHR activation via IDO2/Kyn can promote liver fibrosis [56, 57], while ITE-induced AHR activation in HSCs dampens liver fibrosis [54]. (G) NASH: AHRinduced CD36 [58], FGF21[61], as well as the AHR downstream molecules Cyp1a1 and TNF- $\alpha$ [59] promote NASH. Vice versa, AHRinduced Socs3 [62] and AHR-dependent induction of a Treg versus Th17 predominance [61] attenuate NASH. (H) AHR restricts anti-infectious immunity in Trypanosoma cruzi infection by promoting Tregs and inhibiting Th1 responses and CD8 T cell memory development [46] 
HSCs in liver fibrosis [79] or APCs in immune-mediated diseases [80], are highly desirable. Of note, most of the studies assessing the therapeutic potential of AHR ligands have been conducted in rodents. Yet, human and rodent AHR differ considerably in ligand selectivity [64], indicating that murine studies might under- or overestimate the therapeutic efficacy of specific ligands for potential application in patients. Therefore, future studies in humanized mice and patients are needed to further explore AHR-based therapies in liver disease.

Acknowledgements We thank Johannes Herkel for helpful discussion and critical revision of the manuscript, and the DFG for financial support.

Author contribution A.C. wrote the manuscript. F.A.S. prepared the figures and the tables.

Funding Open Access funding enabled and organized by Projekt DEAL. The authors received funding from the Deutsche Forschungsgemeinschaft - DFG (SFB841).

\section{Declarations}

Conflict of interest The authors declare no competing interests.

Open Access This article is licensed under a Creative Commons Attribution 4.0 International License, which permits use, sharing, adaptation, distribution and reproduction in any medium or format, as long as you give appropriate credit to the original author(s) and the source, provide a link to the Creative Commons licence, and indicate if changes were made. The images or other third party material in this article are included in the article's Creative Commons licence, unless indicated otherwise in a credit line to the material. If material is not included in the article's Creative Commons licence and your intended use is not permitted by statutory regulation or exceeds the permitted use, you will need to obtain permission directly from the copyright holder. To view a copy of this licence, visit http://creativecommons.org/licenses/by/4.0/.

\section{References}

1. Kubes P, Jenne C (2018) Immune responses in the liver. Annu Rev Immunol 36:247-277. https://doi.org/10.1146/annurev-immunol051116-052415

2. Zheng M, Tian Z (2019) Liver-mediated adaptive immune tolerance. Front Immunol 10:2525. https://doi.org/10.3389/fimmu. 2019.02525

3. Carambia A, Frenzel C, Bruns OT, Schwinge D, Reimer R, Hohenberg H, Huber S, Tiegs G, Schramm C, Lohse AW, Herkel J (2013) Inhibition of inflammatory CD4 T cell activity by murine liver sinusoidal endothelial cells. J Hepatol 58:112-118. https://doi. org/10.1016/j.jhep.2012.09.008

4. Neumann K, Rudolph C, Neumann C, Janke M, Amsen D, Scheffold A (2015) Liver sinusoidal endothelial cells induce immunosuppressive IL-10-producing Th1 cells via the Notch pathway. Eur J Immunol 45:2008-2016. https://doi.org/10.1002/eji. 201445346
5. Carambia A, Freund B, Schwinge D, Heine M, Laschtowitz A, Huber S, Wraith DC, Korn T, Schramm C, Lohse AW, Heeren J, Herkel J (2014) TGF- $\beta$-dependent induction of $\mathrm{CD} 4^{+} \mathrm{CD} 25^{+} \mathrm{Foxp}^{+}$Tregs by liver sinusoidal endothelial cells. J Hepatol 61:594-599. https://doi.org/10.1016/j.jhep.2014.04.027

6. Diehl L, Schurich A, Grochtmann R, Hegenbarth S, Chen L, Knolle PA (2008) Tolerogenic maturation of liver sinusoidal endothelial cells promotes $\mathrm{B} 7$-homolog 1-dependent CD8+ T cell tolerance. Hepatology 47:296-305. https://doi.org/10.1002/hep.21965

7. You Q, Cheng L, Kedl RM, Ju C (2008) Mechanism of T cell tolerance induction by murine hepatic Kupffer cells. Hepatology 48:978-990. https://doi.org/10.1002/hep.22395

8. Herkel J, Carambia A, Lohse AW (2020) Autoimmune hepatitis: possible triggers, potential treatments. J Hepatol 73:446-448. https://doi.org/10.1016/j.jhep.2020.03.015

9. Carambia A, Herkel J (2018) Dietary and metabolic modulators of hepatic immunity. Semin Immunopathol 40:175-188. https://doi. org/10.1007/s00281-017-0659-4

10. Shinde R, McGaha TL (2018) The aryl hydrocarbon receptor: connecting immunity to the microenvironment. Trends Immunol 39:1005-1020. https://doi.org/10.1016/j.it.2018.10.010

11. Cella M, Colonna M (2015) Aryl hydrocarbon receptor: linking environment to immunity. Semin Immunol 27:310-314. https:// doi.org/10.1016/j.smim.2015.10.002

12. Gutiérrez-Vázquez C, Quintana FJ (2018) Regulation of the immune response by the aryl hydrocarbon receptor. Immunity 48 : 19-33. https://doi.org/10.1016/j.immuni.2017.12.012

13. Ohtake F, Baba A, Takada I, Okada M, Iwasaki K, Miki H, Takahashi S, Kouzmenko A, Nohara K, Chiba T, Fujii-Kuriyama Y, Kato S (2007) Dioxin receptor is a ligand-dependent E3 ubiquitin ligase. Nature 446:562-566. https://doi.org/10.1038/ nature 05683

14. Dou H, Duan Y, Zhang X, Yu Q, Di Q, Song Y, Li P, Gong Y (2019) Aryl hydrocarbon receptor (AhR) regulates adipocyte differentiation by assembling CRL4B ubiquitin ligase to target PPAR $\gamma$ for proteasomal degradation. J Biol Chem 294:1850418515. https://doi.org/10.1074/jbc.RA119.009282

15. Cervantes-Barragan L, Chai JN, Tianero MD, Di Luccia B, Ahern PP, Merriman J, Cortez VS, Caparon MG, Donia MS, Gilfillan S, Cella M, Gordon JI, Hsieh CS, Colonna M (2017) Lactobacillus reuteri induces gut intraepithelial $\mathrm{CD} 4{ }^{+} \mathrm{CD} 8 \alpha \alpha^{+} \mathrm{T}$ cells. Science 357:806-810. https://doi.org/10.1126/science.aah5825

16. Quintana FJ (2013) Regulation of central nervous system autoimmunity by the aryl hydrocarbon receptor. Semin Immunopathol 35: 627-635. https://doi.org/10.1007/s00281-013-0397-1

17. Esser C, Rannug A (2015) The aryl hydrocarbon receptor in barrier organ physiology, immunology, and toxicology. Pharmacol Rev 67:259-279. https://doi.org/10.1124/pr.114.009001

18. Gargaro M, Scalisi G, Manni G, Mondanelli G, Grohmann U, Fallarino F (2021) The landscape of AhR Regulators and coregulators to fine-tune AhR functions. Int J Mol Sci 22:757. https://doi.org/10.3390/ijms22020757

19. Lee JS, Cella M, McDonald KG, Garlanda C, Kennedy GD, Nukaya M, Mantovani A, Kopan R, Bradfield CA, Newberry RD, Colonna M (2011) AHR drives the development of gut ILC22 cells and postnatal lymphoid tissues via pathways dependent on and independent of Notch. Nat Immunol 13:144-151. https:// doi.org/10.1038/ni.2187

20. Qiu J, Heller JJ, Guo X, Chen ZM, Fish K, Fu YX, Zhou L (2012) The aryl hydrocarbon receptor regulates gut immunity through modulation of innate lymphoid cells. Immunity 36:92-104. https://doi.org/10.1016/j.immuni.2011.11.011

21. Shin JH, Zhang L, Murillo-Sauca O, Kim J, Kohrt HE, Bui JD, Sunwoo JB (2013) Modulation of natural killer cell antitumor activity by the aryl hydrocarbon receptor. Proc Natl Acad Sci U S A 110:12391-12396. https://doi.org/10.1073/pnas.1302856110 
22. Zhang LH, Shin JH, Haggadone MD, Sunwoo JB (2016) The aryl hydrocarbon receptor is required for the maintenance of liverresident natural killer cells. J Exp Med 213:2249-2257. https:// doi.org/10.1084/jem.20151998

23. Bessede A, Gargaro M, Pallotta MT, Matino D, Servillo G, Brunacci C, Bicciato S, Mazza EM, Macchiarulo A, Vacca C, Iannitti R, Tissi L, Volpi C, Belladonna ML, Orabona C, Bianchi R, Lanz TV, Platten M, Della Fazia MA, Piobbico D, Zelante T, Funakoshi H, Nakamura T, Gilot D, Denison MS, Guillemin GJ, DuHadaway JB, Prendergast GC, Metz R, Geffard M, Boon L, Pirro M, Iorio A, Veyret B, Romani L, Grohmann U, Fallarino F, Puccetti P (2014) Aryl hydrocarbon receptor control of a disease tolerance defence pathway. Nature 511:184-190. https://doi.org/ 10.1038 /nature13323

24. Kimura A, Naka T, Nakahama T, Chinen I, Masuda K, Nohara K, Fujii-Kuriyama Y, Kishimoto T (2009) Aryl hydrocarbon receptor in combination with Stat1 regulates LPS-induced inflammatory responses. J Exp Med 206:2027-2035. https://doi.org/10.1084/jem. 20090560

25. Lahvis GP, Lindell SL, Thomas RS, McCuskey RS, Murphy C, Glover E, Bentz M, Southard J, Bradfield CA (2000) Portosystemic shunting and persistent fetal vascular structures in aryl hydrocarbon receptor-deficient mice. Proc Natl Acad Sci U S A 97:10442-10447. https://doi.org/10.1073/pnas.190256997

26. Moreno-Marín N, Merino JM, Alvarez-Barrientos A, Patel DP, Takahashi S, González-Sancho JM, Gandolfo P, Rios RM, Muñoz A, Gonzalez FJ, Fernández-Salguero PM (2018) Aryl hydrocarbon receptor promotes liver polyploidization and inhibits $\mathrm{PI} 3 \mathrm{~K}, \mathrm{ERK}$, and $\mathrm{Wnt} / \beta$-catenin signaling. iScience 4:44-63. https://doi.org/10.1016/j.isci.2018.05.006

27. Walisser JA, Glover E, Pande K, Liss AL, Bradfield CA (2005) Aryl hydrocarbon receptor-dependent liver development and hepatotoxicity are mediated by different cell types. Proc Natl Acad Sci U S A 102:17858-17863. https://doi.org/10.1073/pnas.0504757102

28. Lahvis GP, Bradfield CA (1998) Ahr null alleles: distinctive or different? Biochem Pharmacol 56:781-787. https://doi.org/10. 1016/s0006-2952(98)00134-8

29. Fernandez-Salguero P, Pineau T, Hilbert DM, McPhail T, Lee SS, Kimura S, Nebert DW, Rudikoff S, Ward JM, Gonzalez FJ (1995) Immune system impairment and hepatic fibrosis in mice lacking the dioxin-binding Ah receptor. Science 268:722-726. https://doi.org/ 10.1126/science. 7732381

30. Fernandez-Salguero PM, Ward JM, Sundberg JP, Gonzalez FJ (1997) Lesions of aryl-hydrocarbon receptor-deficient mice. Vet Pathol 34:605-614. https://doi.org/10.1177/030098589703400609

31. Pierre S, Chevallier A, Teixeira-Clerc F, Ambolet-Camoit A, Bui LC, Bats AS, Fournet JC, Fernandez-Salguero P, Aggerbeck M, Lotersztajn S, Barouki R, Coumoul X (2014) Aryl hydrocarbon receptor-dependent induction of liver fibrosis by dioxin. Toxicol Sci 137:114-124. https://doi.org/10.1093/toxsci/kft236

32. Stone TW, Stoy N, Darlington LG (2013) An expanding range of targets for kynurenine metabolites of tryptophan. Trends Pharmacol Sci 34:136-143. https://doi.org/10.1016/j.tips.2012.09.006

33. Kumar S, Wang J, Thomson AW, Gandhi CR (2017) Hepatic stellate cells increase the immunosuppressive function of natural Foxp3+ regulatory $\mathrm{T}$ cells via IDO-induced AhR activation. J Leukoc Biol 10:429-438. https://doi.org/10.1189/jlb.2A0516$239 \mathrm{R}$

34. Abe H, Kimura A, Tsuruta S, Fukaya T, Sakaguchi R, Morita R, Sekiya T, Shichita T, Chayama K, Fujii-Kuriyama Y, Yoshimura A (2014) Aryl hydrocarbon receptor plays protective roles in ConAinduced hepatic injury by both suppressing IFN- $\gamma$ expression and inducing IL-22. Int Immunol 26:129-137. https://doi.org/10.1093/ intimm/dxt049

35. Alam MS, Maekawa Y, Kitamura A, Tanigaki K, Yoshimoto T, Kishihara K, Yasutomo K (2010) Notch signaling drives IL-22 secretion in CD4+ T cells by stimulating the aryl hydrocarbon receptor. Proc Natl Acad Sci U S A 107:5943-5948. https://doi.org/ 10.1073/pnas.0911755107

36. Xu M, Morishima N, Mizoguchi I, Chiba Y, Fujita K, Kuroda M, Iwakura Y, Cua DJ, Yasutomo K, Mizuguchi J, Yoshimoto T (2011) Regulation of the development of acute hepatitis by IL-23 through IL-22 and IL-17 production. Eur J Immunol 41:28282839. https://doi.org/10.1002/eji.201141291

37. Lu Z, Liu J, Liu X, Huang E, Yang J, Qian J, Zhang D, Liu R, Chu Y (2018) MicroRNA 15a/16-1 suppresses aryl hydrocarbon receptor-dependent interleukin-22 secretion in $\mathrm{CD}^{+} \mathrm{T}$ cells and contributes to immune-mediated organ injury. Hepatology 67: 1027-1040. https://doi.org/10.1002/hep.29573

38. Neamah WH, Singh NP, Alghetaa H, Abdulla OA, Chatterjee S, Busbee PB, Nagarkatti M, Nagarkatti P (2019) AhR activation leads to massive mobilization of myeloid-derived suppressor cells with immunosuppressive activity through regulation of CXCR2 and MicroRNA miR-150-5p and miR-543-3p that target antiinflammatory genes. J Immunol 203:1830-1844. https://doi.org/ 10.4049/jimmunol.1900291

39. Katt J, Schwinge D, Schoknecht T, Quaas A, Sobottka I, Burandt E, Becker C, Neurath MF, Lohse AW, Herkel J, Schramm C (2013) Increased $\mathrm{T}$ helper type 17 response to pathogen stimulation in patients with primary sclerosing cholangitis. Hepatology 58: 1084-1093. https://doi.org/10.1002/hep.26447

40. Sebode M, Peiseler M, Franke B, Schwinge D, Schoknecht T, Wortmann F, Quaas A, Petersen BS, Ellinghaus E, Baron U, Olek S, Wiegard C, Weiler-Normann C, Lohse AW, Herkel J, Schramm C (2014) Reduced FOXP3(+) regulatory T cells in patients with primary sclerosing cholangitis are associated with IL2RA gene polymorphisms. J Hepatol 60:1010-1016. https:// doi.org/10.1016/j.jhep.2013.12.027

41. Vuerich M, Harshe R, Frank LA, Mukherjee S, Gromova B, Csizmadia E, Nasser IAM, Ma Y, Bonder A, Patwardhan V, Robson SC, Longhi MS (2021) Altered aryl-hydrocarbonreceptor signalling affects regulatory and effector cell immunity in autoimmune hepatitis. J Hepatol 74:48-57. https://doi.org/10. 1016/j.jhep.2020.06.044

42. Grant CR, Liberal R, Holder BS, Cardone J, Ma Y, Robson SC, Mieli-Vergani G, Vergani D, Longhi MS (2014) Dysfunctional CD39(POS) regulatory T cells and aberrant control of T-helper type 17 cells in autoimmune hepatitis. Hepatology 59:1007-1015. https://doi.org/10.1002/hep.26583

43. Jeffery HC, Hunter S, Humphreys EH, Bhogal R, Wawman RE, Birtwistle J, Atif M, Bagnal CJ, Rodriguez Blanco G, Richardson N, Warner S, Dunn WB, Afford SC, Adams DH, Oo YH (2019) Bidirectional cross-talk between biliary epithelium and Th17 cells promotes local Th17 expansion and bile duct proliferation in biliary liver diseases. J Immunol 203:1151-1159. https://doi.org/10.4049/ jimmunol.1800455

44. She C, Wang J, Tang N, Liu Z, Xu L, Liu B (2020) Effects of 2,3,7, 8 -tetrachlorodibenzo-p-dioxin on $\mathrm{T}$ cell differentiation in primary biliary cholangitis. Biomed Res Int 2020:1754975-1754912. https://doi.org/10.1155/2020/1754975

45. Wang YH, Yang W, Yang JB, Jia YJ, Tang W, Gershwin ME, Ridgway WM, Lian ZX (2015) Systems biologic analysis of T regulatory cells genetic pathways in murine primary biliary cirrhosis. J Autoimmun 59:26-37. https://doi.org/10.1016/j.jaut.2015.01. 011

46. Ambrosio LF, Insfran C, Volpini X, Acosta Rodriguez E, Serra HM, Quintana FJ, Cervi L, Motrán CC (2019) Role of aryl hydrocarbon receptor $(\mathrm{AhR})$ in the regulation of immunity and immunopathology during Trypanosoma cruzi infection. Front Immunol 10: 631. https://doi.org/10.3389/fimmu.2019.00631

47. Patel RD, Murray IA, Flaveny CA, Kusnadi A, Perdew GH (2009) $\mathrm{Ah}$ receptor represses acute-phase response gene expression 
without binding to its cognate response element. Lab Investig 89: 695-707. https://doi.org/10.1038/labinvest.2009.24

48. Krishnan S, Ding Y, Saedi N, Choi M, Sridharan GV, Sherr DH, Yarmush ML, Alaniz RC, Jayaraman A, Lee K (2018) Gut microbiota-derived tryptophan metabolites modulate inflammatory response in hepatocytes and macrophages. Cell Rep 23:1099-1111. https://doi.org/10.1016/j.celrep.2018.03.109 Erratum in: Cell Rep 2019;28:3285

49. Wrzosek L, Ciocan D, Hugot C, Spatz M, Dupeux M, Houron C, Lievin-Le Moal V, Puchois V, Ferrere G, Trainel N, Mercier-Nomé F, Durand S, Kroemer G, Voican CS, Emond P, Straube M, Sokol H, Perlemuter G, Cassard AM (2020) Microbiota tryptophan metabolism induces aryl hydrocarbon receptor activation and improves alcohol-induced liver injury. Gut 2020:gutjnl-2020321565. https://doi.org/10.1136/gutjnl-2020-321565

50. Choi Y, Abdelmegeed MA, Song BJ (2018) Preventive effects of indole-3-carbinol against alcohol-induced liver injury in mice via antioxidant, anti-inflammatory, and anti-apoptotic mechanisms: role of gut-liver-adipose tissue axis. J Nutr Biochem 55:12-25. https://doi.org/10.1016/j.jnutbio.2017.11.011

51. Schneider KM, Elfers C, Ghallab A, Schneider CV, Galvez EJ, Mohs A, Gui W, Candels LS, Wirtz TH, Zuehlke S, Spiteller M, Myllys M, Roulet A, Ouzerdine A, Lelouvier B, Kilic K, Liao L, Nier A, Latz E, Bergheim I, Thaiss CA, Hengstler JG, Strowig T, Trautwein C (2020) Intestinal dysbiosis amplifies acetaminophen induced acute liver injury. Cell Mol Gastroenterol Hepatol S2352345X(20):30181-30188. https://doi.org/10.1016/j.jcmgh.2020.11. 002

52. Schuran FA, Lommetz C, Steudter A, Ghallab A, Wieschendorf B, Schwinge D, Zuehlke S, Reinders J, Heeren J, Lohse AW, Schramm C, Herkel J, Carambia A (2021) Aryl hydrocarbon receptor activity in hepatocytes sensitizes to hyperacute acetaminopheninduced hepatotoxicity in mice. Cell Mol Gastroenterol Hepatol 11: 371-388. https://doi.org/10.1016/j.jcmgh.2020.09.002

53. Yang W, Yu T, Huang X, Bilotta AJ, Xu L, Lu Y, Sun J, Pan F, Zhou J, Zhang W, Yao S, Maynard CL, Singh N, Dann SM, Liu Z, Cong Y (2020) Intestinal microbiota-derived short-chain fatty acids regulation of immune cell IL-22 production and gut immunity. Nat Commun 11:4457. https://doi.org/10.1038/s41467-020-18262-6

54. Yan J, Tung HC, Li S, Niu Y, Garbacz WG, Lu P, Bi Y, Li Y, He J, Xu M, Ren S, Monga SP, Schwabe RF, Yang D, Xie W (2019) Aryl hydrocarbon receptor signaling prevents activation of hepatic stellate cells and liver fibrogenesis in mice. Gastroenterology 157 : 793-806.e14. https://doi.org/10.1053/j.gastro.2019.05.066

55. Zhang Z, Gao Z, Hu W, Y in S, Wang C, Zang Y, Chen J, Zhang J, Dong L (2013) 3,3'-Diindolylmethane ameliorates experimental hepatic fibrosis via inhibiting miR-21 expression. Br J Pharmacol 170:649-660. https://doi.org/10.1111/bph.12323

56. Fabre T, Molina MF, Soucy G, Goulet JP, Willems B, Villeneuve JP, Bilodeau M, Shoukry NH (2018) Type 3 cytokines IL-17A and IL-22 drive TGF- $\beta$-dependent liver fibrosis. Sci Immunol 3: eaar7754. https://doi.org/10.1126/sciimmunol.aar7754

57. Hoshi M, Osawa Y, Nakamoto K, Morita N, Yamamoto Y, Ando T, Tashita C, Nabeshima T, Saito K (2020) Kynurenine produced by indoleamine 2,3-dioxygenase 2 exacerbates acute liver injury by carbon tetrachloride in mice. Toxicology 438:152458. https://doi. org/10.1016/j.tox.2020.152458

58. Lee JH, Wada T, Febbraio M, He J, Matsubara T, Lee MJ, Gonzalez FJ, Xie W (2010) A novel role for the dioxin receptor in fatty acid metabolism and hepatic steatosis. Gastroenterology 139:653-663. https://doi.org/10.1053/j.gastro.2010.03.033

59. Xia H, Zhu X, Zhang X, Jiang H, Li B, Wang Z, Li D, Jin Y (2019) Alpha-naphthoflavone attenuates non-alcoholic fatty liver disease in oleic acid-treated HepG2 hepatocytes and in high fat diet-fed mice. Biomed Pharmacother 118:109287. https://doi.org/10.1016/ j.biopha.2019.109287
60. Zhu XY, Xia HG, Wang ZH, Li B, Jiang HY, Li DL, Jin R, Jin Y (2020) In vitro and in vivo approaches for identifying the role of aryl hydrocarbon receptor in the development of nonalcoholic fatty liver disease. Toxicol Lett 319:85-94. https://doi.org/10.1016/j. toxlet.2019.10.010

61. Lu P, Yan J, Liu K, Garbacz WG, Wang P, Xu M, Ma X, Xie W (2015) Activation of aryl hydrocarbon receptor dissociates fatty liver from insulin resistance by inducing fibroblast growth factor 21. Hepatology 61:1908-1919. https://doi.org/10.1002/hep.27719

62. Wada T, Sunaga H, Miyata K, Shirasaki H, Uchiyama Y, Shimba S (2016) Aryl hydrocarbon receptor plays protective roles against high fat diet (HFD)-induced hepatic steatosis and the subsequent lipotoxicity via direct transcriptional regulation of Socs 3 gene expression. J Biol Chem 291:7004-7016. https://doi.org/10.1074/jbc. M115.693655

63. Liu Y, She W, Wang F, Li J, Wang J, Jiang W (2014) 3, 3'Diindolylmethane alleviates steatosis and the progression of NASH partly through shifting the imbalance of Treg/Th17 cells to Treg dominance. Int Immunopharmacol 23:489-498. https:// doi.org/10.1016/j.intimp.2014.09.024

64. Murray IA, Patterson AD, Perdew GH (2014) Aryl hydrocarbon receptor ligands in cancer: friend and foe. Nat Rev Cancer 14:801814. https://doi.org/10.1038/nrc3846

65. Shibata Y, Hara T, Nagano J, Nakamura N, Ohno T, Ninomiya S, Ito H, Tanaka T, Saito K, Seishima M, Shimizu M, Moriwaki H, Tsurumi $H$ (2016) The role of indoleamine 2,3-dioxygenase in diethylnitrosamine-induced liver carcinogenesis. PLoS One 11: e0146279. https://doi.org/10.1371/journal.pone.0146279

66. Wang LT, Chiou SS, Chai CY, Hsi E, Yokoyama KK, Wang SN, Huang SK, Hsu SH (2017) Intestine-specific homeobox gene ISX Integrates IL6 signaling, tryptophan catabolism, and immune suppression. Cancer Res 77:4065-4077. https://doi.org/10.1158/00085472

67. Wang Y, Yao R, Zhang L, Xie X, Chen R, Ren Z (2019) IDO and intra-tumoral neutrophils were independent prognostic factors for overall survival for hepatocellular carcinoma. J Clin Lab Anal 33: e22872. https://doi.org/10.1002/jcla.22872

68. Li S, Li L, Wu J, Song F, Qin Z, Hou L, Xiao C, Weng J, Qin X, Xu J (2020) TDO promotes hepatocellular carcinoma progression. Onco Targets Ther 13:5845-5855. https://doi.org/10.2147/OTT. S252929

69. Svobodová J, Procházková J, Kabátková M, Krkoška M, Šmerdová L, Líbalová H, Topinka J, Kléma J, Kozubík A, Machala M, Vondráček J (2019) 2,3,7,8-Tetrachlorodibenzo-p-dioxin (TCDD) disrupts control of cell proliferation and apoptosis in a human model of adult liver progenitors. Toxicol Sci 172:368-384. https://doi. org $/ 10.1093 /$ toxsci/kfz202

70. Procházková J, Kabátková M, Bryja V, Umannová L, Bernatík O, Kozubík A, Machala M, Vondrácek J (2011) The interplay of the aryl hydrocarbon receptor and $\beta$-catenin alters both AhRdependent transcription and $\mathrm{Wnt} / \beta$-catenin signaling in liver progenitors. Toxicol Sci 122:349-360. https://doi.org/10.1093/toxsci/ kfr129

71. Vondráček J, Machala M (2016) Environmental ligands of the aryl hydrocarbon receptor and their effects in models of adult liver progenitor cells. Stem Cells Int 2016:4326194. https://doi.org/10.1155/ 2016/4326194

72. Moreno-Marín N, Barrasa E, Morales-Hernández A, Paniagua B, Blanco-Fernández G, Merino JM, Fernández-Salguero PM (2017) Dioxin receptor adjusts liver regeneration after acute toxic injury and protects against liver carcinogenesis. Sci Rep 7:10420. https:// doi.org/10.1038/s41598-017-10984-w

73. Ko S, Russell JO, Molina LM, Monga SP (2020) Liver progenitors and adult cell plasticity in hepatic injury and repair: knowns and unknowns. Annu Rev Pathol 15:23-50. https://doi.org/10.1146/ annurev-pathmechdis-012419-032824 
74. Safe S, Lee SO, Jin UH (2013) Role of the aryl hydrocarbon receptor in carcinogenesis and potential as a drug target. Toxicol Sci 135: 1-16. https://doi.org/10.1093/toxsci/kft128

75. Cheong JE, Sun L (2018) Targeting the IDO1/TDO2-KYN-AhR pathway for cancer immunotherapy - challenges and opportunities. Trends Pharmacol Sci 39:307-325. https://doi.org/10.1016/j.tips. 2017.11.007

76. Murray IA, Perdew GH (2020) How ah receptor ligand specificity became important in understanding its physiological function. Int $\mathrm{J}$ Mol Sci 21:9614. https://doi.org/10.3390/ijms21249614

77. Safe S, Jin UH, Park H, Chapkin RS, Jayaraman A (2020) Aryl hydrocarbon receptor (AHR) ligands as selective AHR modulators (SAhRMs). Int J Mol Sci 21:6654. https://doi.org/10.3390/ ijms 21186654

78. Dolciami D, Ballarotto M, Gargaro M, López-Cara LC, Fallarino F, Macchiarulo A (2020) Targeting Aryl hydrocarbon receptor for next-generation immunotherapies: selective modulators
(SAhRMs) versus rapidly metabolized ligands (RMAhRLs). Eur J Med Chem 185:111842. https://doi.org/10.1016/j.ejmech.2019. 111842

79. Zhang Z, Wang C, Zha Y, Hu W, Gao Z, Zang Y, Chen J, Zhang J, Dong L (2015) Corona-directed nucleic acid delivery into hepatic stellate cells for liver fibrosis therapy. ACS Nano 9:2405-2419. https://doi.org/10.1021/nn505166x

80. Kenison JE, Jhaveri A, Li Z, Khadse N, Tjon E, Tezza S, Nowakowska D, Plasencia A, Stanton VP Jr, Sherr DH, Quintana FJ (2020) Tolerogenic nanoparticles suppress central nervous system inflammation. Proc Natl Acad Sci U S A 117:32017-32028. https://doi.org/10.1073/pnas.2016451117

Publisher's note Springer Nature remains neutral with regard to jurisdictional claims in published maps and institutional affiliations. 